A

$€$

\title{
OPINIA PRAWNA W SPRAWIE BRAKU MOŻLIWOŚCI ODPOWIEDZIALNOŚCI ZA NARUSZENIE DÓBR OSOBISTYCH ZA TREŚĆ OGÓLNYCH OCEN ZAWARTYCH W KAZANIACH ${ }^{1}$
}

Niniejsza opinia odnosi się wprost do treści kazania abpa Józefa Michalika wygłoszonego w dniu 16 października 2013 r. w archikatedrze wrocławskiej podczas sprawowania liturgii Mszy św. Kazanie to stało się następnie podstawą do roszczeń cywilno-prawnych za rzekome naruszenie dóbr osobistych. Prezentowana opinia zawiera dwie części: analizę cywilnoprawną oraz odniesienie się do podstaw aksjologicznych systemu prawa, tj. praw człowieka.

\section{PRAWO CYWILNE - DOBRA OSOBISTE}

Rozpoczynając analizę przedmiotowego zagadnienia zdefiniować należy podstawowe pojęcia, ponieważ wydaje się, że ich niezrozu-

* Dr, Wydział Prawa i Nauk Społecznych, Wyższa Szkoła Finansów i Prawa w Bielsku-Białej, ul. Tańskiego 5, 43-382 Bielsko-Biała; Wydział Prawa i Administracji, Uniwersytet Rzeszowski, ul. Grunwaldzka 13, 35-068 Rzeszów, e-mail: mchajda@o2.pl.

** Dr, Katedra Praw Człowieka, Wydział Prawa, Prawa Kanonicznego i Administracji, Katolicki Uniwersytet Lubelski Jana Pawła II, Al. Racławickie 14, 20-950 Lublin, e-mail: michal.skwarzynski@gmail.com, adwokat, członek Izby Adwokackiejw Lublinie.

${ }^{1}$ Opinia prawna sporządzona na rzecz Senatora RP Pana Kazimierza Jaworskiego, w zw. z wykonywaniem mandatu posła i senatora. 
mienie jest źródłem dalszego procedowania w sprawie cywilnej oraz błędnego przekazu medialnego na temat tej sprawy.

Rozważania dotyczą odpowiedzialności duchownego za treść wygłoszonego kazania w czasie Mszy Świętej. Istotny jest poniższy fragment kazania:

„Wiele dziś się mówi i stusznie o karygodnych nadużyciach dorostych wobec dzieci. Tego rodzaju zła nie wolno tolerować, ale nikt nie odważy się pytać o przyczyny, żadna stacja telewizyjna nie walczy z pornografia, z promocja fatszywej, egoistycznej mitości między ludźmi. Nikt nie upomina się za dziećmi cierpiącymi przez brak mitości rozwodzących się rodziców, a to sa rany bolesne i dlugotrwate.

Na naszych oczach następuje promocja nowej ideologii gender. Już kilkanaście najważniejszych uniwersytetów w Polsce wprowadziło wykłady z tej nowej i niezbyt jasnej ideologii, której programowa radę stanowia najbardziej agresywne polskie feministki, które od lat szydza z Kościoła $i$ etyki tradycyjnej, promuja aborcję $i$ walcza z tradycyjnym modelem rodziny i wierności matżeńskiej.

Ideologia gender budzi stuszny niepokój, jako że odchodzi od praw natury, promuje tzw. związi matżeńskie między osobami jednej ptci, walczy o prawo legalizacji adopcji dziecka przez takie pary, a ostatnio wkracza do przedszkoli i szkót z instrukcja o tym, że należy od najmłodszych lat wygasić w dziecku poczucie wstydu i pouczyć je o możliwościach czerpania cielesnych przyjemności wbrew etyce naturalnej, a nawet o możliwościach manipulowania ptcia, aż do dowolnego wyboru obranej ptci."

Analiza treści powyższego kazania abpa Józefa Michalika w oderwaniu od komentarzy do tego kazania wyrażonych w prasie wskazuje, że nie może ono stanowić naruszenia dóbr osobistych kogokolwiek.

Jest tak dlatego, że wypowiedź taka nie narusza istoty dóbr osobistych, jaką jest indywidualność. Wynika to z definiowania pojęcia dobra osobistego ${ }^{2}$. Oczywiście początkowo dominowała definicja

${ }^{2}$ Szerzej zob. Michał Skwarzyński, „Odpowiedzialność dziennikarza za naruszenie dóbr osobistych," w: Ogólnopolski Zjazd Cywilistów Studentów - 45 lat kodeksów cywilnych, red. Józef J. Skoczylas i in. (Lublin: Wydawnictwo KUL, 2009), 59-61. 
subiektywistyczna Stefana Grzybowskiego ${ }^{3}$, który określał dobra osobiste jako: „pewne wartości związane ściśle z jednostka ludzka, pewne indywidualne wartości świata uczuć, stanu życia psychicznego człowieka, dobra nie majątkowe, co nie wytacza, że maja one również znaczenie w sferze majatkowej"

Inną dominującą obecnie koncepcję wysunęli jednak A. Szpunar ${ }^{5}$ i Z. Radwański, którzy zaproponowali, aby przez dobra osobiste rozumieć: „uznane przez system prawny wartości (...), obejmujace fizyczna i psychiczna integralność człowieka, jego indywidualność oraz godność i pozycje w społeczeństwie, co stanowi przesłankę samorealizacji osoby ludzkiej" ". Teoria ta, zwaną obiektywną zajmuje dzisiaj pozycję dominującą $\mathrm{w}$ doktrynie i orzecznictwie.

Co prawda, już w 1972 r., Sędzia Sądu Najwyższego Henryk Dąbrowski, w komentarzu do Kodeksu cywilnego słusznie argumentował, iż: „,wydaje się też, że zupetnie ścisła i równocześnie wyczerpujaca definicja [dóbr osobistych - przyp. M.Ch./M.S.] bytaby nie możliwa" , to jednak w spornych przypadkach w praktyce stosuje się ujęcie zaproponowane przez Andrzeja Ciska, który określa dobra osobiste jako: ,wartości o charakterze niemajątkowym, ściśle związane z osoba ludzka, decydujace o jej bycie, pozycji w społeczeństwie, a będace wyrazem jej odrębności psychicznej i fizycznej oraz możliwości twórczych, uznane powszechnie w spoleczeństwie i akceptowane przez dany system prawny".

Tym samym, w przypadku dóbr osobistych, kluczowe znaczenie ma indywidualny ich charakter. Zatem wypowiedzi o charakterze nieozna-

${ }^{3}$ Szerzej zob. Jacek Sadomski, Naruszenie dóbr osobistych przez media (Warszawa: Oficyna Naukowa IWS, 2003), 15; Jacek Chaciński, Prawa podmiotowe a ochrona dóbr osobistych (Lublin: Wydawnictwo KUL, 2004), 105.

${ }^{4}$ Aleksander Wolter, Jerzy Ignatowicz, i Krzysztof Stefaniuk, Prawo Cywilne, zarys części ogólnej (Warszawa: LexisNexis, 2001), 182

${ }^{5}$ Szerzej zob. Sadomski, Naruszenie, 15.

${ }^{6}$ Zbigniew Radwański, Prawo cywilne - część ogólna (Warszawa: C.H. Beck, 2005), 161.

${ }^{7}$ H. Dąbrowski, w: Kodeks cywilny komentarz, tom I, red. Zbigniew Resich (Warszawa: Wydawnictwo Prawnicze, 1972), 90.

${ }^{8}$ A. Cisek, w: Kodeks cywilny. Komentarz, tom I, red. Edward Gniewek (Warszawa: C.H. Beck, 2004), 87. 
czonym, nieadresowane do konkretnego podmiotu (osoby fizycznej czy prawnej) czy zindywidualizowanej grupy, w ogóle nie dotykają dobra osobistego. Co więcej, dobra osobiste nie są pozbawione elementu obiektywnego, więc nie jest tak, że wyłącznie subiektywne przekonanie osoby decyduje o naruszeniu dóbr osobistych. W orzecznictwie można wskazać na dwa kluczowe w tym zakresie judykaty.

Pierwszy to Wyrok Sądu Najwyższego z dnia 6 kwietnia 2004 r. w sprawie sygn. akt I CK 484/03, gdzie wskazano: „Należy zauwa$\dot{z} y c ́, \dot{z} e$ w prawie polskim nie ma ustawowej definicji dobra osobistego, a z konstrukcji art. 23 i 24 k.c. wynika, iż przedmiotem ochrony sa wszelkie dobra osobiste, których liczba jest nieograniczona, gdyż $w$ miare zmieniajacych się $w$ świadomości społecznej ocen wartościujących, ustalenie wyczerpującego katalogu dóbr osobistych nie byłoby ani możliwe, ani pożadane. $W$ konsekwencji, orzecznictwu i nauce pozostawiono rozstrzyganie o tym, czy i kiedy mamy do czynienia z dobrem osobistym, które podlega ochronie prawa. Początkowo definiowano dobra osobiste jako indywidualne wartości świata uczuć i życia psychicznego człowieka. Później nastapiło rozwinięcie i uściślenie tych definicji przez wskazanie, że indywidualne wartości o tyle tylko stanowia prawem chronione dobra osobiste, o ile odpowiadaja obiektywnym kryteriom, a nie tylko subiektywnym odczuciom osoby żadajacej ochrony prawnej. Tym obiektywnym kryterium i punktem odniesienia weryfikujacym subiektywne przekonanie, przyjmujace określona wartość za dobra osobiste, powinna być wyrażana przez spoleczeństwo (lub jego zdecydowana większość) opinia o tym, czy konkretna wartość zastuguje na uznanie jej za prawem chronione dobro osobiste. Przesadzenie przez ustawodawce, że bezpośrednim przedmiotem ochrony jest dobro osobiste, zakłada, iż temu dobru odpowiada określone prawo, zatem jest tyle praw osobistych, ile chronionych dóbr. Ustawodawstwu polskiemu obca jest więc konstrukcja jednego, ogólnego prawa podmiotowego jako prawa osobistości. Prawo to, jako element osobowości człowieka zwiąane jest pojęciem nadrzędnym, którego desygnatami sa nieograniczone co do liczby, poszczególne podmiotowe prawa osobiste."

Następnie w tym orzeczeniu Sąd Najwyższy analizował dobra osobiste w postaci kultu pamięci osoby zmarłej oraz ochrony uczuć 
religijnych, w tym właśnie kontekście. Sąd Najwyższy wskazał, że: „,dobro osobiste, będace emanacja osobowości każdego człowieka, jest sprawa jego świadomości, a więc kategoria subiektywna, ale z drugiej strony nie jest pozbawione elementów obiektywnych i tym samym musi odpowiadać kryterium sprawdzalności, a więc kryterium obiektywnym. Kryterium tym jest odpowiedni stosunek bliskości do osoby zmarłej, będacy źródtem istnienia dobra osobistego u jego podmiotu, ale jednocześnie czynnikiem kształtującym jego treść i zakres wypływajacych z niego uprawnien"” oraz że ,rolę kryterium obiektywnego może petnić także stosunek bliskości osoby zainteresowanej".

Wskazane przez Sąd Najwyższy przesłanki pozwalają na twierdzenie, że wypowiedź naruszająca dobra osobiste musi indywidualnie naruszać dobra osobiste, co powinno być obiektywnie sprawdzalne. W przedmiotowej sprawie nie można jednak powiązać żadnych słów kazania, zwłaszcza tych wytłuszczonych w powyższym cytacie, z konkretną osobą, bądź ze zindywidualizowaną grupą osób. Wypowiedzi te mają charakter dopuszczalnych ocen i mają walor elementu szerszej wypowiedzi, o określonej spójnej strukturze. Zatem nie można tych słów „wyrywać z kontekstu”. Wypowiedzi te nie były adresowane do kogokolwiek, a były fragmentem wzmacniającym wypowiedź i podnoszone argumenty.

Odnosi się do tego kolejne orzeczenie, tj. Wyrok Sądu Apelacyjnego w Warszawie z dnia 12 marca 2013 r., w sprawie sygn. akt I ACa 1034/12, gdzie stwierdzono, że: „,konstrukcja ochrony dóbr osobistych opiera się $w$ prawie polskim na obiektywnym ujmowaniu ich istoty. Odmiennie niż w ujęciu subiektywnym, odwołujacym się przede wszystkim do indywidualnych wartości świata uczuć, stanu życia psychicznego jednostki, koncepcja obiektywna przyjmuje, że źródłem dóbr osobistych, jako wartości niemajątkowych i ściśle zwiazanych z osobą ludzka, jest porzadek prawny oraz zawarte $w$ nim społeczne normy $i$ oceny. Dobra osobiste charakteryzowane sa więc jako wartości wynikajace ze społecznych ocen, stanowiace przedmiot społecznego uznania i typizacji, o których istnieniu rozstrzyga osąd opinii społecznej. Sa to wartości uznane powszechnie $w$ społeczeństwie i akceptowane przez dany system prawny (zob. m.in. A. Szpunar, Ochrona dóbr osobistych, Warszawa 1979, s. 107; A. Cisek, Dobra osobiste i ich niemajątkowa 
ochrona $w$ kodeksie cywilnym, Acta UWr, Prawo CLXVII, Wroctaw 1989, s. 39; Z. Radwański, Prawo cywilne - część ogólna, Warszawa 2003, s. 156). Z tych względów naturę i granice poszczególnych dóbr osobistych wyznaczaja przewazajace $w$ danym społeczeństwie zapatrywania prawne, moralne i obyczajowe. Dokonujac oceny, czy nastapiło naruszenie danego dobra osobistego należy odnosić się do pogladów panujacych $w$ spoleczeństwie, postugiwać się w tym celu abstrakcyjnym wzorcem "przeciętnego obywatela», nie zaś odwoływać się do jednostkowych odczuć i ocen osoby pokrzywdzonej.

Jak wskazuje się w doktrynie, wartości osobiste nie dlatego podlegają ochronie, że dana osoba przywiazuje do nich subiektywnie donioste znaczenie, ale dlatego, że system prawny uznaje i aprobuje potrzebę ich ochrony. Również w orzecznictwie Sądu Najwyższego akcentuje się poglad, zgodnie z którym ocena, czy w konkretnej sytuacji nastapiło naruszenie dobra osobistego, nie może być dokonywana wedtug miary indywidualnej wrażliwości pokrzywdzonego, a więc wedtug oceny subiektywnej zainteresowanego. Kryteria oceny naruszenia musza być poddane obiektywizacji, trzeba $w$ tym zakresie uwzględnić odczucia szerszego grona uczestników i powszechnie przyjmowane, a zastugujace na akceptację normy postepowania, w tym normy obyczajowe i wynikajace z tradycji (tak m.in. wyrok SN z 11 marca 1997 r., III CKN 33/97, OSNC 1997, z. 6-7, poz. 93, wyrok SN z 16 stycznia 1976 r., II CR 692/75, OSNC 1976, z. 11, poz. 251). W świetle powyższego nie każde zdarzenie wywołujace u jednostki „subiektywne wzburzenie emocjonalne” stanowi fakt, któremu można przypisać skutek w postaci naruszenia dóbr osobistych jednostki. Owych kryterium delimitacyjnych dostarcza obiektywna koncepcja naruszenia dóbr osobistych".

Dalej Sąd Apelacyjny stwierdza, że „Tym obiektywnym kryterium i punktem odniesienia weryfikujacym istniejace subiektywne przekonanie, przyjmujace określona wartość za dobra osobiste, powinna być wyrażana przez społeczeństwo (lub jego zdecydowana większość) opinia o tym, czy konkretna wartość zastuguje na uznanie jej za prawem chronione dobro osobiste".

$\mathrm{Z}$ tych powodów Sąd Apelacyjny przyjął, że nie można akceptować koncepcji tzw. grupowych praw podmiotowych. Wypowiedzi zawarte w kazaniu tj. ,egoistycznej mitości między ludźmi” ,przez brak miłości 
rozwodzacych się rodziców” "najbardziej agresywne polskie feministki" nie odnoszą się do jakiejkolwiek osoby bądź zindywidualizowanej grupy osób. Z punktu widzenia treści stanowią one w istocie ocenę.

Oceny zaś nie można traktować w kategoriach odpowiedzialności czy cywilnej czy karnej, z uwagi, że są one emanacją wolności poglądów i wolności słowa i nie mogą być poddane kategoryzacji prawda / fałsz. Odpowiedzialność cywilna za ocenę byłaby dopuszczalna wyłącznie, gdyby dotyczyła konkretnej osoby i była z gruntu fałszywa. Nie można uznać za naruszającą prawo oceny, z którą ktoś się wyłącznie nie zgadza. Ocena zjawisk społecznych (dysfunkcji rodzin) czy kryminalnych (pedofilia) i próba poszukiwania odpowiedzi na pytanie o przyczyny tych zjawisk nie może prowadzić do odpowiedzialności prawnej. Stanowi to bowiem wyłącznie ocenę dokonaną przez konkretną jednostkę takich zdarzeń, co powinno prowadzić do jedynej dopuszczalnej reakcji, jaką jest polemika z zaprezentowanym przez adwersarza stanowiskiem. Niewłaściwym byłoby prowadzenie debaty i ścieranie poglądów na gruncie odpowiedzialności prawnej, a nie na gruncie argumentów.

Podsumowując analizę istoty dóbr osobistych należy przyjąć, że aby doszło do naruszenia dobra osobistego musi być ono indywidualne, więc nie grupowe, a jednocześnie naruszenie musi być obiektywnie sprawdzalne. Obiektywizm ten musi polegać w przypadku treści wypowiedzi na wskazaniu szczególnej więzi indywidualnej $\mathrm{z}$ treścią tej wypowiedzi, co można obiektywnie ocenić jako odnoszące się do tej osoby. Zawarte w kazaniu treści nie mogą być połączone z żadnym indywidualnym dobrem osobistym.

Kolejną przeszkodą do uznania naruszenia dóbr osobistych przez treść kazania abpa Józefa Michalika są mechanizmy ochrony dóbr osobistych ${ }^{9}$. Artykuł $23 \mathrm{kc}$ określa katalog przykładowych dóbr osobi-

${ }^{9}$ Kodeks cywilny, art. 24: $\S 1$. Ten, czyje dobro osobiste zostaje zagrożone cudzym działaniem, może żądać zaniechania tego działania, chyba że nie jest ono bezprawne. W razie dokonanego naruszenia może on także żądać, ażeby osoba, która dopuściła się naruszenia, dopełniła czynności potrzebnych do usunięcia jego skutków, w szczególności ażeby złożyła oświadczenie odpowiedniej treści i w odpowiedniej formie. Na zasadach przewidzianych 
stych $^{10}$, natomiast $\mathrm{w}$ art. $24 \mathrm{kc}$ wskazane są przesłanki ochrony dóbr osobistych: bezprawność naruszenia lub zagrożenie jakiegoś dobra osobistego.

Jednak jak widać regulacje zawarte w normie z art. 23 i 24 kc cechuje wysoki stopień ogólności. Dlatego określenie szczegółowych przesłanek odpowiedzialności musiała wziąć na siebie doktryna i orzecznictwo. Doprowadziło to do krystalizacji i werbalizacji cech dóbr osobistych. Są one prawami podmiotowymi, o charakterze bezwzględnym - erga omnes - skutecznymi przeciwko wszystkim. Są również niezbywalne, ściśle związane z podmiotem i wygasają wraz ze śmiercią osoby fizycznej lub likwidacją osoby prawnej. $Z$ praw podmiotowych mogą wynikać roszczenia niemajątkowe, które nie ulegają przedawnieniu. Z przepisu art. $24 \mathrm{kc}$ wynika domniemanie bezprawności, co w ewidentny sposób jest korzystne dla pokrzywdzonego, ponieważ dowód co do działania w ramach prawa musi przedstawić pozwany. Być może te cechy dóbr osobistych mogą wynikać z dorobku nauki i orzecznictwa, jednak niektóre aspekty realizacji odpowiedzialności za naruszenie dóbr osobistych również kształtowały doktryna i orzecznictwo. Najważniejszą z nich było przyjęcie, że odpowiedzialność za naruszenie dóbr osobistych jest uniezależniona od winy i następuje jedynie w oparciu o kryterium obiektywnej bezprawności naruszenia. Konstrukcję tę wypracowała doktryna i orzecznictwo ${ }^{11}$, a oczywistym jest, że to kluczowa cecha determinująca odpowiedzialność.

w kodeksie może on również żądać zadośćuczynienia pieniężnego lub zapłaty odpowiedniej sumy pieniężnej na wskazany cel społeczny.

$\S 2$. Jeżeli wskutek naruszenia dobra osobistego została wyrządzona szkoda majątkowa, poszkodowany może żądać jej naprawienia na zasadach ogólnych.

$\S 3$. Przepisy powyższe nie uchybiają uprawnieniom przewidzianym w innych przepisach, w szczególności w prawie autorskim oraz w prawie wynalazczym.

${ }^{10}$ Kodeks cywilny, art. 23: Dobra osobiste człowieka, jak w szczególności zdrowie, wolność, cześć, swoboda sumienia, nazwisko lub pseudonim, wizerunek, tajemnica korespondencji, nietykalność mieszkania, twórczość naukowa, artystyczna, wynalazcza i racjonalizatorska, pozostają pod ochroną prawa cywilnego niezależnie od ochrony przewidzianej w innych przepisach.

${ }^{11}$ Szerzej zob. H. Dąbrowski, dz. cyt., 94 i powołane tam orzecznictwo i literatura; K. Piasecki, dz. cyt., 42 i powołane tam orzeczenie Sądu Najwyższego (z 6 grudnia 1967 r., II CR 318/67, Gazeta Sądowa i Penitencjarna 10 (1968), 2). 
Obecnie realizacja odpowiedzialności za naruszenie dóbr osobistych wymaga wykazania jej podstawy, czyli bezprawności działania.

Do okoliczności wyłączających bezprawność naruszenia dóbr osobistych należy zaliczyć: działanie w granicach porządku prawnego, wykonywanie prawa podmiotowego, ochrona interesu spolecznego, które mają zastosowanie w niniejszej sprawie, jak również zezwolenie uprawnionego, sprzeczność żądania ochrony z zasadami współżycia społecznego ${ }^{12}$.

Największe znaczenie ma ocena dość oczywistego faktu, czy arcybiskup może w kościele wygłosić kazanie. Odpowiedź jest oczywiście twierdząca, więc już z faktu, że duchowny korzysta z wolności wypowiedzi - prawa podmiotowego wynika, że nie sposób przyjąć jednoczesnej bezprawności koniecznej do przypisania mu odpowiedzialności za naruszenie dóbr osobistych. Wzmacnia to ochrona innego prawa podmiotowego - wolności wyznania. Kwestia ta zostanie szerzej omówiona w drugiej części opinii.

Znaczenie w sprawie ma również tzw. ochrona interesu publicznego (nazywana też obroną społecznie uzasadnionego interesu). Obie w/w instytucje wyłączają bezprawność i uniemożliwiają przypisanie odpowiedzialności za naruszenie dóbr osobistych.

W zakresie dobra osobistego - czci, wytworzyła się wyjątkowa okoliczność uchylająca bezprawność tj. prawo do krytyki ${ }^{13}$. W jego ramach „można powiedzieć” więcej zwłaszcza na tematy występujące w aktualnej debacie publicznej. Co więcej, oceny w ramach prawa do krytyki mogą być ostre, z uwagi na przedmiot tej krytyki czy ważkość tematu. Ewidentna chęć ochrony rodziny i dziecka, jaka wynika z całego tekstu kazania abpa Józefa Michalika, a nie tekstu celowo uproszczonych przekazów prasowych, pozwala na stosowanie ostrych ocen, co jednak nie podlega odpowiedzialności na gruncie prawa polskiego.

Ponadto nie można pomijać, że wypowiedź abpa Józefa Michalika była $\mathrm{w}$ istocie zgodna $\mathrm{z}$ wolą samego ustawodawcy, czego przejawem jest art. $56 \S 2$ kodeksu rodzinnego i opiekuńczego, który zakazu-

12 Szerzej zob. Chaciński, Prawa, 117.

${ }^{13}$ Zob. H. Dąbrowski, dz. cyt., 94; K. Piasecki, dz. cyt., 41; Wyrok Sądu Najwyższego z dnia 19 listopada 1968 r. sygn. akt II CR 291/68, OSNCP 1969, poz. 200. 
je rozwodu w przypadku, gdy miałoby to się odbyć kosztem dobra małoletnich dzieci. Prawodawca w oczywisty sposób uznaje, że rodzina jest najlepszym środowiskiem dla rozwoju dziecka. Podobnie jest z całym systemem regulacji chroniących dzieci przed pedofilią.

\section{PODSTAWY AKSJOLOGICZNE - PRAWA CZŁOWIEKA}

Fundamentem powyższych rozwiązań prawa cywilnego jest odniesienie się do ważkich dóbr leżących u podstawy każdego systemu prawnego czyli praw człowieka. $Z$ oczywistych względów analiza nie ma charakteru kompleksowego, a dotyczy jedynie istotnych z punktu widzenia opinii elementów. Widać to już na gruncie orzecznictwa sądów polskich. Cytowany wyżej Wyrok Sądu Najwyższego z dnia 6 kwietnia 2004 r. w sprawie sygn. akt I CK 484/03, gdzie odnoszono się do art. 53 Konstytucji RP, więc wolności sumienia i wyznania. Natomiast Wyrok Sądu Apelacyjnego w Warszawie z dnia 12 marca 2013 r., w sprawie sygn. akt I ACa 1034/12 wprost stwierdza, że: ,istnieje bowiem oczywista kolizja zasad prawnych $w$ postaci prawa jednostki do ochrony czci $i$ dobrego imienia oraz prawa do swobody wypowiedzi $i$ wolności słowa (swoboda wypowiedzi obejmuje równiez wypowiedzi komercyjne). Obydwie wskazane zasady sa chronione zarówno na podstawie Konstytucji RP (art. 14 i art. 54 ust. 1 oraz art. 30, art. 31 ust. 3 i art. 47), umów międzynarodowych (art. 10 ust. 1 i 2 Konwencji o ochronie praw człowieka $i$ podstawowych wolności, art. 19 powszechnej deklaracji praw człowieka, art. 17 i 19 międzynarodowego paktu praw obywatelskich i politycznych)".

Wyjściem dla dalszych rozważań jest rozważenie czy sąd, więc państwo, w imieniu którego sąd działa ma prawo ingerować w sferę wolności związku wyznaniowego, tj. w zakres i sferę treści kazania.

Stwierdzić należy, że w systemie ochrony praw człowieka ogromne znaczenie ma podział na prawa i wolności ${ }^{14}$. Zgodzić się należy, że

${ }^{14}$ Zbigniew Hołda, w: Prawa Człowieka, Zarys wykładu, red. Zbigniew Hołda, Dorota Ostrowska, Joanna Hołda, Julita A. Rybczyńska (Warszawa: Wolters Kluwer Polska, 2011), 11 oraz Krzysztof Motyka, „Wprowadzenie,” w: Krzysztof Motyka, Prawa Człowieka, 
definicja wolności ,jest nader sporna $i$ trudna do uchwycenia"15, to jednak ,wolność stanowi fundamentalny, naturalny (pierwotny wobec prawa stanowionego) $i$ chroniony prawnie atrybut ludzkiej egzystencji, dotyczacy możliwości autonomicznego i autentycznego rozporzadzania przez człowieka soba, swobodnego wyboru i realizowania wartości oraz nieskrępowanego kierowania swoim postępowaniem. Wolność przejawia się w różnych aspektach, częściowo tylko definiowanych i normowanych przez prawo stanowione, poprzez tworzenie pozytywnych warunków ich realizacji oraz ustalenie negatywnych granic zakresu korzystania z uprawnień $w$ ramach dopuszczalnych ingerencji prawnych" 16 . Wolność jest to sfera możności postępowania w określony sposób np. działania albo zaniechania, w którą państwu zakazuje się ingerencji, jest to więc prawo w znaczeniu negatywnym, a jednostka $w$ ramach swojej woli z wolności korzysta bądź nie. Dlatego też państwo nie jest całkiem zwolnione $\mathrm{z}$ działania na rzecz ochrony wolności i polega ona na wyznaczeniu koniecznych jej granic. W sytuacji istnienia wolności prawnie chronionej „,należy odróżnić trzy proste modalności: zakaz ingerencji państwa, zakaz ingerencji dla innych podmiotów, nakazu udzielenia ochrony prawnej przez państwo"17.

Tym samym należy postawić pytanie czy osoby w związku wyznaniowym mają wolność do organizacji i przebiegu uroczystości religijnych. Odpowiedź jest oczywiście pozytywna. Zatem związek wyznaniowy i osoba wskazana przez ten związek, w tym przypadku arcybiskup Józef Michalik korzystają z wolności wyznania, w którą państwo nie może ingerować. Odrzucenie tej tezy skutkowałoby określaniem treści kazań przez państwo, co kojarzy się z zakusami czasów słusznie

Wprowadzenie, Wybór Źródet (Lublin: Oficyna Wydawnicza Verba, 2004), 20; szerzej zob. M. Skwarzyński, „Bluźnierstwo w świetle standardów ochrony praw człowieka,” w: Odpowiedzialność karna artysty za obrazę uczuć religijnych, red. Filip Ciepły (Warszawa: Instytut na rzecz Kultury Prawnej Ordo Iuris, 2014), 91-95, M. Skwarzyński, „Sprzeciw sumienia w europejskim i krajowym systemie ochrony praw człowieka," Przeglad Sejmowy 6 (2013): 18-19.

${ }^{15}$ Dariusz Dudek, w: Zasady Ustroju III Rzeczpospolitej, red. Dariusz Dudek i in. (Warszawa: Wolters Kluwer business, 2009), 105.

${ }^{16}$ Tamże, 105.

${ }^{17}$ Anna Michalska, Podstawowe prawa człowieka w prawie wewnętrznym a pakty praw człowieka (Warszawa: Wydawnictwo Prawnicze, 1976), 64. 
minionych. Kazanie ze swej istoty jest wygłaszane w ramach związku wyznaniowego, więc w ramach realizacji wolności tego związku. $\mathrm{Z}$ istoty wolności wynika zakaz ingerencji. Przedmiot sprawy wskazuje, że chodzi „o pozwanie arcybiskupa”, który jest duchownym w związku, a nie pozwanie obywatela polskiego Józefa Michalika. Tym samym taki zakres postępowania powoda w sprawie powinien przez sąd zostać potraktowany, jako próba wciągnięcia sądu w ingerencję w wolność związku wyznaniowego i naruszenia jego autonomii przyznanej przez polskie prawo. Zgodnie z art. 8 ust. 2 Konkordatu między Stolicą Apostolską i Rzecząpospolitą Polską, podpisanego w Warszawie dnia 28 lipca 1993 r. ${ }^{18}$ : „organizowanie kultu publicznego należy do władzy kościelnej zgodnie z przepisami prawa kanonicznego i z zachowaniem odpowiednich przepisów prawa polskiego". Stosowanie odpowiednio przepisów prawa polskiego nie może jednak dotyczyć treści kazania, w którym realizuje się także prawo do prezentowania własnego nauczania. Stanowiłoby to ingerencję w wolność religijną związku i wolność religijną duchownego. Odpowiedniość może dotyczyć wyłącznie traktowania kazania, jak wypowiedzi publicznej świeckiej osoby. W przedmiotowej sprawie kontekst wskazuje, że celem działania jest pozwanie duchownego, jako duchownego.

Przechodząc dalej, przyjmując nawet, że sprawa dotyczy nie arcybiskupa, a obywatela Józefa Michalika, który miał publiczne wystąpienie, a nie kazanie, należy stwierdzić, że korzystał on, jak każdy człowiek z przysługujących mu praw i wolności człowieka. Prawa człowieka próbuje się definiować na kształt rozumienia prawa podmiotowego w prawie cywilnym, jako przyznaną przez przepisy (normę) prawa i wynikającą ze stosunku prawnego sferę możności postępowania danego podmiotu w określony sposób ${ }^{19}$. Prawem człowieka jest więc taka sfera, w której człowiek może realizować swoją: wolność, uprawnienie, lub/i kompetencję ${ }^{20}$, lecz państwo w tym wypadku musi zacho-

${ }^{18}$ Dz.U. z 1998 r. Nr 51, poz. 318.

${ }^{19}$ K. Motyka, Wprowadzenie, 18; Wolter, Ignatowicz, i Stefaniuk, Prawo Cywilne, 128 in.

${ }^{20}$ Piotr Tuleja, Stosowanie Konstytucji RP w świetle zasady jej nadrzędności (wybrane problemy) (Kraków: Zakamycze, 2003), 135; podobnie Michalska, Podstawowe, 62. 
wać się aktywnie i zapewnić ochronę prawa poprzez tworzenie norm w prawie pozytywnym. Prawo człowieka jest to więc taki rodzaj wolności, uprawnienia bądź kompetencji, który jednostka chcąc zrealizować, ma prawo żądać od państwa ochrony w realizacji, którą państwo musi jej zapewnić. Cechą specyficzną praw człowieka jest to, że zobowiązane do przestrzegania praw człowieka po pierwsze jest państwo. W założeniu poprzez ten system ochrony jednostce ma być zapewnione bezpieczeństwo przed negatywnym działaniem aparatu państwowego, jak i nakazanie państwu ochrony praw i wolności jednostek.

Podstawowym prawem człowieka jakie realizował Józef Michalik jest wolność wypowiedzi. Wskazującym na istotę tego prawa jest pogląd, iż odpowiednim terminem określającym tę wolność jest „wolność ekspresji” "21, choć w doktrynie wskazuje się również ,swobodę wypowiedzi"22. Bezspornym w doktrynie jest, że normy wyrażające wolność słowa są źródłem swobody artystycznej, satyry czy krytyki.

Trafnie zauważono, że w przypadku art. 10 ust. 1 EKPCz nie istnieje w zasadzie kategoria ,wypowiedzi niechronionych" tym przepisem ${ }^{23}$, tym samym w świetle standardów strasburskich kazanie korzysta $z$ wolności wypowiedzi i jest chronione konwencją. Elementami wolności słowa są: wolność posiadania poglądów oraz prawo do otrzymywania oraz przekazywania informacji i idei ${ }^{24}$. W Europejskiej Konwencji Praw Człowieka wskazano, w art. 10 ust. 1 że wolność słowa ,obejmuje wolność posiadania pogladów oraz otrzymywania i przekazywania informacji i idei bez ingerencji władz publicznych $i$ bez względu na granice państwowe". Podobną treść

${ }^{21}$ Rafał Mizerski, w: Prawa człowieka i ich ochrona - podręcznik dla studentów prawa i administracji, red. Tadeusz Jasudowicz, Bożena Gronowska, Michał Balcerzak, Maciej Lubiszewski, i Rafał Mizerski (Toruń: Dom Organizatora, 2005), 328.

${ }^{22}$ Marek A. Nowicki, Wokół Konwencji Europejskiej. Komentarz do Europejskiej Konwencji Praw Człowieka (Warszawa: Wolters Kluwer Polska, 2009), 413.

${ }^{23}$ Leszek Garlicki, „Komentarz do art. 10 EKPCz,” w: Leszek Garlicki, Piotr Hofmański, i Andrzej Wróbel, Konwencja o ochronie praw człowieka i podstawowych wolności. Komentarz do artykułów 1-18, t. I (Warszawa: C.H. Beck, 2010), 594, pkt 15.

${ }^{24}$ Stwierdzić należy, że wyrażenie wolność słowa, nie może skutkować traktowaniem uprawnień z niej wynikających jako ,wolności”, a nie ,praw”. Semantyka w tym przypadku nie zmienia charakteru tych uprawnień i wynikających stąd obowiązków państwa. 
zawiera Karta Praw Podstawowych ${ }^{25}$ w art. 11 ust. $1^{26}$, która co prawda w Polsce wydaje się nie jest bezpośrednim źródłem prawa, ponieważ zgodnie z art. 1 ust. 1 Protokołu ,brytyjskiego" załączonego do Traktatu z Lizbony wobec Polski, jak i Zjednoczonego Królestwa nie można skutecznie powołać się na jej treść ${ }^{27}$, to jednak ,standardy zawarte w KPP w Polsce obowiazują, badź jako standardy konstytucyjne, bądź jako obowiazujace nas standardy międzynarodowe"28.

Z kolei Międzynarodowy Pakt Praw Obywatelskich i Politycznych ${ }^{29} \mathrm{w}$ art. 19 ust. 1 określa, że ,każdy człowiek ma prawo do posiadania bez przeszkód własnych pogląów”, zaś art. 19 ust. 2 mówi, że ,każdy człowiek ma prawo do swobodnego wyrażania opinii; prawo to obejmuje swobode poszukiwania, otrzymywania i rozpowszechniania wszelkich informacji i pogladów, bez względu na granice państwowe, ustnie, pismem lub drukiem, w postaci dzieła sztuki bądź w jakikolwiek inny sposób wedtug własnego wyboru".

Drugim prawem człowieka, które realizował Józef Michalik i jako obywatel i jako arcybiskup jest prawo do wolności przekonań i wyznania. Artykuł 9 EKPCz określa w ustępie pierwszym, że ,każdy ma prawo do wolności myśli, sumienia $i$ wyznania; prawo to obejmuje wolność zmiany wyznania lub przekonań oraz wolność uzewnętrzniania indywidualnie lub wspólnie z innymi, publicznie lub prywatnie, swego

${ }^{25}$ Z dnia 7 grudnia 2000 r., Dz.Urz. UE. z 2010 r., C. 83, s. 389, dalej jako: KPP.

${ }^{26}$, „Każdy ma prawo do wolności wypowiedzi. Prawo to obejmuje wolność posiadania pogladów oraz otrzymywania $i$ przekazywania informacji $i$ idei bez ingerencji władz publicznych i bez względu na granice państwowe”.

${ }^{27}$ Szerzej zob. Anna Wyrozumska, „Ochrona praw podstawowych w Unii Europejskiej,” w: Obywatel Unii. Tom VI Traktat z Lizbony, Izabela Skomerska-Muchowska, Anna Wyrozumska (Warszawa: Instytut Wydawniczy EuroPrawo, 2010), 219 i n. oraz Krystyna Kowalik-Bańczyk, Konsekwencje przyjęcia protokołu polsko-brytyjskiego dotyczace stosowania Karty Praw Podstawowych, w: Karta Praw Podstawowych w europejskim i krajowym porządku prawnym, red. Andrzej Wróbel (Warszawa: Wolters Kluwer Polska, 2009), 136-138.

${ }^{28}$ Roman Wieruszewski, „Postanowienia Karty Praw Podstawowych w świetle wiążących Polskę umów międzynarodowych i postanowień Konstytucji RP z 1997 r.," w: Ochrona praw podstawowych w Unii Europejskiej, red. Jan Barcz (Warszawa: C.H. Beck, 2008), 143.

${ }^{29}$ Otwarty do podpisu w Nowym Jorku dnia 19 grudnia 1966 r. Załącznik do Dz.U. z 1977 r. Nr 38, poz. 167 - dalej MPPOiP. 
wyznania lub przekonań przez uprawianie kultu, nauczanie, praktykowanie i czynności rytualne".

Podkreślić należy, że w orzecznictwie strasburskim prawo do wolności słowa ma charakter kluczowy, a w tym przypadku korzystanie $\mathrm{z}$ niej jest wsparte prawem do wolności wyznania. W przedmiotowym przypadku z uwagi na doniosłość wypowiedzi, jej cel, jakim była ochrona rodziny i dziecka uzasadniał pojedyncze niezindywidualizowane oceny przyczyn negatywnych zjawisk społecznych.

Wskazać należy również, że nie zostały spełnione przesłanki klauzul limitacyjnych z art. 9 ust. $2 \mathrm{EKPCz}^{30}$ i 10 ust. $2 \mathrm{EKPCz}^{31}$. Aby było możliwe ograniczenie korzystania z wolności wyznania i wolności słowa musi ono wynikać z ustawy. Powyższa analiza wskazuje, że w sprawie nie może chodzić o naruszenie dóbr osobistych jakiejkolwiek osoby. Dlatego też już ta okoliczność oznacza naruszenie praw człowieka. Procedowanie sądu dotyczy bowiem sprawy, której nie ma przedmiotu wynikającego z ustawy. Co więcej, ograniczenie takie, jakim jest sam tok postępowania nie jest niezbędne w społeczeństwie demokratycznym, które z istoty ma charakter pluralistyczny ${ }^{32}$, gdzie w oczywisty sposób jednostki muszą liczyć się z innymi opiniami wyrażanymi

${ }^{30}$ Wolność uzewnętrzniania wyznania lub przekonań może podlegać jedynie takim ograniczeniom, które sa przewidziane przez ustawe $i$ konieczne $w$ społeczeństwie demokratycznym z uwagi na interesy bezpieczeństwa publicznego, ochronę porzadku publicznego, zdrowia i moralności lub ochronę praw $i$ wolności innych osób.

${ }^{31}$ Korzystanie z tych wolności pociagajacych za soba obowiązi i odpowiedzialność może podlegać takim wymogom formalnym, warunkom, ograniczeniom i sankcjom, jakie sa przewidziane przez ustawe $i$ niezbędne $w$ społeczeństwie demokratycznym $w$ interesie bezpieczeństwa państwowego, integralności terytorialnej lub bezpieczeństwa publicznego ze względu na konieczność zapobieżenia zakłóceniu porządku lub przestępstwu, z uwagi na ochronę zdrowia $i$ moralności, ochronę dobrego imienia i praw innych osób oraz ze względu na zapobieżenie ujawnieniu informacji poufnych lub na zagwarantowanie powagi i bezstronności władzy sadowej.

${ }^{32}$ Szerzej zob. Krzysztof Orzeszyna, Podstawy relacji między państwem a kościołami w konstytucjach państw członkowskich i traktatach Unii Europejskiej. Studium prawnoporównawcze (Lublin: Wydawnictwo KUL, 2007), 23-34. Na temat zorganizowanego społeczeństwa obywatelskiego szerzej zob. Krzysztof Orzeszyna, „Społeczeństwo Obywatelskie w Unii Europejskiej," Teka Komisji Prawniczej Polskiej Akademii Nauk Oddział w Lublinie 2 (2009), 94-108; Antoni Kość, „Relacja prawa i wartości w społeczeństwie otwartym,” w: Prawo a wartości. Księga jubileuszowa Profesora Józefa Nowackiego, red. Iwona Bogucka, Zygmunt Tobor (Kraków: Zakamycze, 2003), 135. 
publicznie. Tok postępowania, gdzie w oczywisty sposób sprawa nie ma przedmiotu - naruszenia dóbr osobistych, polegający na wezwaniu strony pozwanej reprezentowanej przez fachowego pełnomocnika wywołuje oczywisty efekt chłodzący w debacie publicznej. Poza tym stanowi on niebezpieczny precedens. Zgodnie z zasadą równości wobec prawa, jeśli takie wezwanie jest możliwe wobec duchownego, to jest także możliwe wobec dziennikarzy, naukowców, czy choćby osób objętych immunitetem. Z punktu widzenia prawa cywilnego pozwać można niemal o wszystko, wobec czego taka praktyka może służyć odrywaniu od obowiązków, poprzez konieczność stawienia się w sądzie w sprawie w istocie bezprzedmiotowej. Może to prowadzić w skrajnych przypadkach do celowej dezorganizacji redakcji prasowych poprzez wzywanie na bezpodstawne sprawy dziennikarzy czy tłumieniu wolności w nauce. Taki precedens nie odnosiłby się wyłącznie do osób duchownych.

KONKLUZJA

I. W przedmiotowej sprawie nie ma przesłanek do realizacji odpowiedzialności cywilnej z tytułu dóbr osobistych:

1. Brak jest naruszenia indywidualnego dobra osobistego;

2. Działanie nie było bezprawne;

3. Wypowiedzi miały charakter ocen niepodlegających odpowiedzialności prawnej;

4. Działanie było realizacją wolności wyznania i wolności słowa;

5. Działanie było podjęte w społecznie uzasadnionym interesie.

II. Przedmiotowa sprawa ingeruje w prawa i wolności człowieka jakie przysługują arcybiskupowi Józefowi Michalikowi:

1. Wolność wyznania została naruszona poprzez prowadzenie postępowania sądowego w zakresie treści wygłoszonego w czasie uroczystości religijnej kazania;

2. Wolność wypowiedzi została naruszona poprzez prowadzenie postępowania sądowego w zakresie niewynikającym z przepisów ustawy, ponieważ w sprawie w sposób oczywisty nie doszło do naruszeń dóbr osobistych 


\section{WNIOSKI}

W przedmiotowej sprawie arcybiskup Józef Michalik nie jest traktowany, jak każdy inny obywatel i jest w istocie dyskryminowany z uwagi na wyznanie i funkcję duszpasterską. Wobec przeciętnego „Kowalskiego" tego typu postępowanie byłoby oddalone, bez wzywania stron z powodu braku przedmiotu dla takiego procesu. Wydaje się, że wyłącznie funkcja duszpasterska jest powodem toczenia się niniejszej sprawy, ponieważ brak do tego jakichkolwiek podstaw prawnych. W istocie arcybiskup jest traktowany inaczej, to znaczy gorzej niż każdy inny obywatel polski. Stanowi to naruszenie zakazu dyskryminacji określonego w art. 32 ust. 1 i 2 Konstytucji RP oraz art. 14 Europejskiej Konwencji Praw Człowieka, gdzie wskazuje się, że nie można być dyskryminowanym z jakiejkolwiek przyczyny, zwłaszcza z powodu wyznania czy wykonywanego zawodu. Podsumowując, sprawa niniejsza, jak każda o pozorne naruszenie dóbr osobistych powinna być oddalona bez wzywania strony, reprezentowanej przez fachowego pełnomocnika. W takiej sytuacji sąd powinien ograniczyć postępowanie do zagadnień wstępnych na podstawie art. $220 \mathrm{kpc}$ i stwierdzić, że przedmiotowe kazanie nie mogło naruszać niczyich dóbr osobistych.

\section{BIBLIOGRAFIA}

Chaciński, Jacek. Prawa podmiotowe a ochrona dóbr osobistych. Lublin: Wydawnictwo KUL, 2004.

Garlicki, Leszek, Piotr Hofmański, i Andrzej Wróbel. Konwencja o ochronie praw człowieka i podstawowych wolności. Komentarz do artykułów 1-18, t. I. Warszawa: C.H. Beck, 2010.

Michalska, Anna. Podstawowe prawa człowieka $w$ prawie wewnętrznym a pakty praw człowieka. Warszawa: Wydawnictwo Prawnicze, 1976.

Motyka, Krzysztof. Prawa Człowieka, Wprowadzenie, Wybór Źródet. Lublin: Oficyna Wydawnicza Verba, 2004.

Nowicki, Marek A. Wokót Konwencji Europejskiej. Komentarz do Europejskiej Konwencji Praw Człowieka. Warszawa: Wolters Kluwer Polska, 2009. 
Orzeszyna, Krzysztof. Podstawy relacji między państwem a kościołami $w$ konstytucjach państw członkowskich $i$ traktatach Unii Europejskiej. Studium prawnoporównawcze. Lublin: Wydawnictwo KUL, 2007.

Orzeszyna, Krzysztof. „Społeczeństwo Obywatelskie w Unii Europejskiej.” Teka Komisji Prawniczej Polskiej Akademii Nauk Oddziat w Lublinie 2 (2009), 94-108.

Prawa Człowieka, Zarys wykładu, red. Zbigniew Hołda, Dorota Ostrowska, Joanna Hołda, i Julita A. Rybczyńska. Warszawa: Wolters Kluwer Polska, 2011.

Prawa człowieka i ich ochrona - podręcznik dla studentów prawa i administracji, red. Tadeusz Jasudowicz, Bożena Gronowska, Michał Balcerzak, Maciej Lubiszewski, i Rafał Mizerski. Toruń: Dom Organizatora, 2005.

Radwański, Zbigniew. Prawo cywilne - część ogólna. Warszawa: C.H. Beck, 2005.

Sadomski, Jacek. Naruszenie dóbr osobistych przez media. Warszawa: Oficyna Naukowa IWS, 2003.

Skwarzyński, Michał. „Odpowiedzialność dziennikarza za naruszenie dóbr osobistych.” W: Ogólnopolski Zjazd Cywilistów Studentów - 45 lat kodeksów cywilnych, red. Józef J. Skoczylas i in, 59-70. Lublin: Wydawnictwo KUL, 2009.

Skwarzyński, Michał. „Bluźnierstwo w świetle standardów ochrony praw człowieka." W: Odpowiedzialność karna artysty za obrazę uczuć religijnych, red. Filip Ciepły, 91-95. Warszawa: Instytut na rzecz Kultury Prawnej Ordo Iuris, 2014.

Skwarzyński, Michał. „Sprzeciw sumienia w europejskim i krajowym systemie ochrony praw człowieka." Przeglad Sejmowy 6 (2013): 9-26.

Tuleja, Piotr. Stosowanie Konstytucji RP w świetle zasady jej nadrzędności (wybrane problemy). Kraków: Zakamycze, 2003.

Wolter, Aleksander, Jerzy Ignatowicz, i Krzysztof Stefaniuk. Prawo Cywilne, zarys części ogólnej. Warszawa: LexisNexis, 2001. 


\section{LEGAL OPINION ON THE LACK OF LIABILITY FOR THE INFRINGEMENT OF PERSONAL RIGHTS FOR THE CONTENT OF GENERAL JUDGEMENTS CONTAINED IN SERMONS}

\section{Summary}

Opinion law concerns the problem of the possibility of legal liability liability for infringement of personal rights - to be general speech, contained in a sermon, delivered by a priest. The opinion refers to the content of the sermon of Archbishop Jozef Michalik delivered on 16th October 2013 in Wrocław Cathedral during the liturgy of the Mass. The sermon has become the basis for civil law claims for apparent infringement of personal rights. Opinion showed that in the present case there is no reason to implement liability for the infringement of personal rights. It also indicated that suing the Archbishop of and the course of the case violated the human right to freedom of speech and human right to freedom of conscience and religion.

Tłumaczenie własne autorów

Key words: priest, sermon, personal rights, the human right to freedom of speech, human right to freedom of conscience and religion, freedom of conscience and religion

Słowa kluczowe: duchowny, kazanie, dobra osobiste, prawo człowieka do wolności słowa, prawo człowieka do wolności sumienia i wyznania, wolność sumienia i wyznania 